\title{
Estimation of Engel curves for household expenditure on dry bean and processed bean in Mexico
}

\author{
Antonio AGUILAR-LOPEZ ${ }^{1}$, Salvador GONZÁLEZ-ANDRADE ${ }^{2}$, Aleš KUHAR ${ }^{3,4}$ \\ Received January 06, 2020; accepted May 04, 2020. \\ Delo je prispelo 06. januarja 2020, sprejeto 04. maja 2020
}

\section{Estimation of Engel curves for household expenditure on dry bean and processed bean in Mexico}

Abstract: Dry bean is the leading source of low-cost plant-based proteins in Mexico. However, in the years following the liberalization of the economy, Mexico experienced the erosion of a self-sufficiency index for this commodity. Impending changes in the international markets for proteins compel us to reevaluate the role of dry bean for Mexico's food security. In the present paper we set out to analyze the last link of the marketing chain in Mexico's dry bean market: the consumer. Using data on household expenditure for 2018, the relationship between income and expenditure on dry bean as well as on processed bean is ascertained by means of the Working-Leser Engel Curve equations system. Due to the presence of zero-expenditure households in the sample, we followed the two-step Heckit procedure for the possible selection bias. The results suggest that the budget share for dry bean and for processed bean drops as income increases. The corrected conditional elasticity for dry bean is -0.1056 . For processed bean, the elasticity is -0.2286 . The negative sign indicates that both commodities are inferior goods.

Key words: plant production; plant based proteins; dry bean; economics; Engel curves; household income; food selfsufficiency; Mexico
Ocena Engelovih krivulj za izdatke gospodinjstev za suhi in predelani fižol v Mehiki

Izvleček: Suhi fižol je v Mehiki najpomembnejši cenovno ugoden vir rastlinskih beljakovin, vendar je Mehika v letih po liberalizaciji gospodarstva doživela padec indeksa samooskrbe za to proizvodno skupino. Zaradi bližajočih se sprememb $\mathrm{v}$ ureditvi mednarodne trgovine, ki bodo vplivale tudi na trgovanje $\mathrm{z}$ beljakovinsko bogatimi kmetijskimi surovinami, smo želeli ponovno oceniti pomen suhega fižola za prehransko varnost v Mehiki. V pričujočem prispevku smo analizirali zadnji člen tržne verige za suhi fižol na mehiškem trgu, potrošnika. Z uporabo podatkov o izdatkih gospodinjstev za leto 2018 smo razmerje med dohodkom in odhodki za suh in predelan fižol ugotavljali z uporabo Working-Leser-jevega sistema Engelovih krivulj. Zaradi prisotnosti gospodinjstev, ki niso imela tovrstnih stroškov, smo upoštevali dvostopenjski Heckit-ov postopek za korekcijo morebitne napake pri vzorčenju. Rezultati kažejo, da se delež proračuna za suh in predelan fižol zmanjšuje, ko se dohodek gospodinjstev povečuje. Korigirana pogojna elastičnost za suhi fižol je -0.1056 . Za predelan fižol je elastičnost $-0,2286$. Negativni predznak potrjuje status inferiornih dobrin za obe proučevani kategoriji.

Ključne besede: poljččine; rastlinske beljakovine; suhi fižol; ekonomika; Engelove krivulje; dohodki gospodinjstev; prehranska varnost; Mehika

Instituto Tecnológico Superior de Huichapan, División de Ingeniería en Gestión Empresarial, Huichapan, México

2 El Colegio de la Frontera Norte, Departamento de Estudios Económicos, Tijuana, México

3 University of Ljubljana, Biotechnical Faculty, Department of Animal Science, Ljubljana, Slovenia

4 Corresponding author, e-mail: ales.kuhar@bf.uni-lj.si 


\section{INTRODUCTION}

A notion echoed in several academic and institutional settings around the world suggests that plant-based proteins should account for a larger share of the human intake of these nutrients, replacing animal-based sources to some extent. This partial replacement is seen as an economic and environmental necessity, feasible in nutritional terms, and strategically unavoidable for the achievement of food security goals at the national and international levels. The strategic dimension is especially significant in the Developing Countries, which rely more on plant-based sources of protein (Grigg, 1995).

Although there is still uncertainty about the degree whereby climate change and the depletion of natural resources could threaten the capacity to sustain the rates of growth in agricultural output observed during the previous decades (Valin et al., 2014), the expectation is that the prices of grains and meat will increase in the long-run even if global food supply increases (Aiking, 2011).

Although average meat consumption stagnates and even declines as income increases (Vranken et al., 2014), different strategies have been suggested to adapt human diets to meet sustainability challenges (De Boer et al., 2014), one among them being the substitution of animalbased proteins for plant-based proteins (Westhoek et al., 2014).

The instrumental use of pulses in a range of areas, namely: food security, nutrition, health, sustainable agriculture and climate mitigation, is such that 2016 was declared the International Year of Pulses by the United
Nations General Assembly (Calles et al., 2019). However, to fully harness these potentials, actions need to be taken in order to reverse the decline in consumption of pulses witnessed worldwide (implying a change, yet again, in consumer preferences), to encourage production (which currently takes place in marginal areas) and to further the development of their marketing chains.

The present paper is an attempt at characterizing the last link of Mexico's dry bean marketing chain, i.e., consumption, as well as other factors that ought to be considered when designing policies aimed at tackling challenges in the areas mentioned before.

Dry bean is an important source of protein, among other nutrients, in the human food supply; in fact, dry bean contains $15-25 \%$ of protein on a dry weight basis, depending on the variety (Sathe, 2002). In Mexico, this pulse is one of the leading sources of plant-based proteins, it is the second annual crop by planted area, and it has a historical relationship with the inhabitants of the country, which is deemed as the center of origin of a number of varieties.

Four factors that could affect food security regarding the availability and prices of proteins at the national level are: a) changes in agricultural productivity levels due to climate change (Parry et al., 2004), b) the conflict between animal-based sources and plant-based sources for the natural resources required for their production, as well as the interaction between their production processes and the so-called planetary boundaries (Stehfest et al., 2009), c) changes in the consumption pattern of proteins in countries such as China and India, due to income and population growth (Gandhi \& Zhou, 2014), and d) the trans-
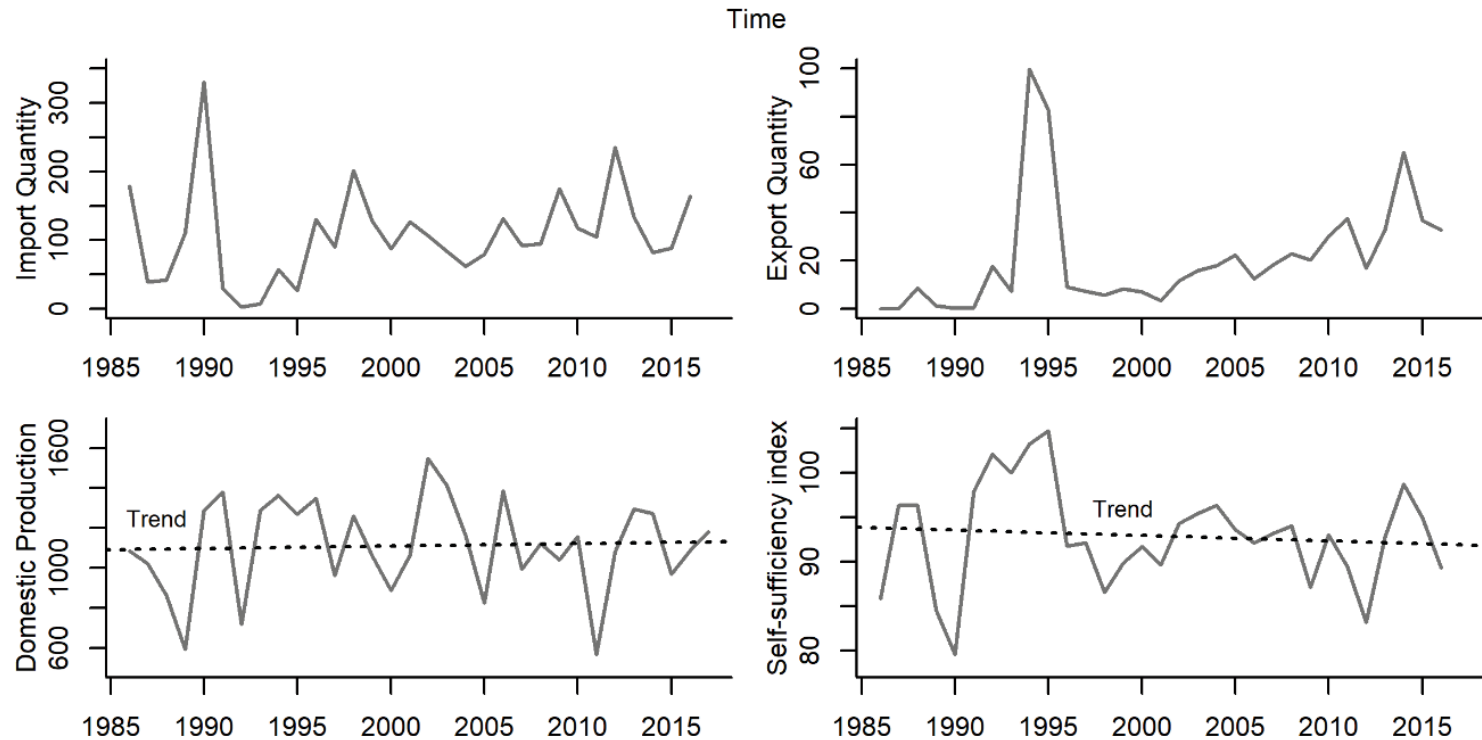

Figure 1: Components and tendency of Mexico's self-sufficiency index for dry bean (1986-2017); quantities in thousand metric tons. Source: own elaboration with data from FAO, 2019) 
Table 1: Average budget share (\%) for dry bean and processed bean by income decile (quarterly data), 2008-2018

\begin{tabular}{|c|c|c|c|c|c|c|c|c|c|c|c|}
\hline \multirow[b]{2}{*}{ ENIGH $^{1}$} & \multicolumn{10}{|c|}{ Income decile $^{2}$} & \multirow[b]{2}{*}{ Code } \\
\hline & $\mathrm{I}^{3}$ & II & III & IV & $\mathrm{V}$ & VI & VII & VIII & IX & $\mathrm{X}$ & \\
\hline 2008 & 3.590 & 1.507 & 1.023 & 0.854 & 0.616 & 0.517 & 0.376 & 0.277 & 0.174 & 0.084 & A137 \\
\hline 2010 & 3.920 & 1.586 & 1.066 & 0.774 & 0.527 & 0.516 & 0.425 & 0.262 & 0.161 & 0.067 & Dry bean \\
\hline 2012 & 3.198 & 1.519 & 1.384 & 0.900 & 0.711 & 0.532 & 0.421 & 0.286 & 0.176 & 0.087 & \\
\hline 2014 & 2.389 & 1.220 & 0.831 & 0.708 & 0.519 & 0.420 & 0.305 & 0.238 & 0.152 & 0.070 & \\
\hline 2016 & 2.216 & 1.148 & 0.792 & 0.624 & 0.490 & 0.387 & 0.306 & 0.230 & 0.150 & 0.072 & \\
\hline 2018 & 2.245 & 1.026 & 0.715 & 0.540 & 0.452 & 0.340 & 0.284 & 0.210 & 0.136 & 0.065 & \\
\hline 2008 & 0.155 & 0.120 & 0.063 & 0.082 & 0.065 & 0.051 & 0.046 & 0.029 & 0.027 & 0.020 & A142 \\
\hline 2010 & 0.099 & 0.106 & 0.077 & 0.075 & 0.049 & 0.056 & 0.049 & 0.036 & 0.024 & 0.016 & Proc. bean \\
\hline 2012 & 0.187 & 0.127 & 0.096 & 0.105 & 0.086 & 0.076 & 0.057 & 0.042 & 0.046 & 0.011 & \\
\hline 2014 & 0.205 & 0.108 & 0.066 & 0.068 & 0.060 & 0.057 & 0.053 & 0.050 & 0.032 & 0.024 & \\
\hline 2016 & 0.183 & 0.138 & 0.117 & 0.100 & 0.093 & 0.088 & 0.068 & 0.057 & 0.046 & 0.022 & \\
\hline 2018 & 0.210 & 0.152 & 0.127 & 0.110 & 0.100 & 0.086 & 0.079 & 0.060 & 0.048 & 0.024 & \\
\hline
\end{tabular}

${ }^{1}$ Following the procedure whereby the expenditure on other foodstuffs reported in the 'concentrado' tables were obtained. ${ }^{2}$ The expansion factor was used when determining the income deciles. ${ }^{3}$ Budget share for households with no income was set to 0 for decile I. Source: own elaboration with data from INEGI, 2019a.

mission of price spikes from international to domestic markets (Bekkers et al., 2017).

World production of dry beans grew steadily between 1986 and 2017, period in which it went from 17,1 to 31,4 million tons. Mexico ranked among the top ten world producers during this interval; however, its production level didn't follow this upward trend. In fact, Mexico's domestic production averaged 1,11 million tons during the same period, with significant year-over-year variations. At the same time, dry bean imports (mainly from the U.S.) showed a positive trend, but so did the relatively less significant exports (FAO, 2019). On the other hand, Mexico's population went from 81.2 million in 1990 to 119.9 million in 2015 (INEGI, 2019b). When analyzing these trends, it can be inferred that per capita consumption of dry bean among Mexicans dropped in the years after the liberalization of the economy started; yet, Mexico witnessed the slightly eroding tendency of a self-sufficiency index for
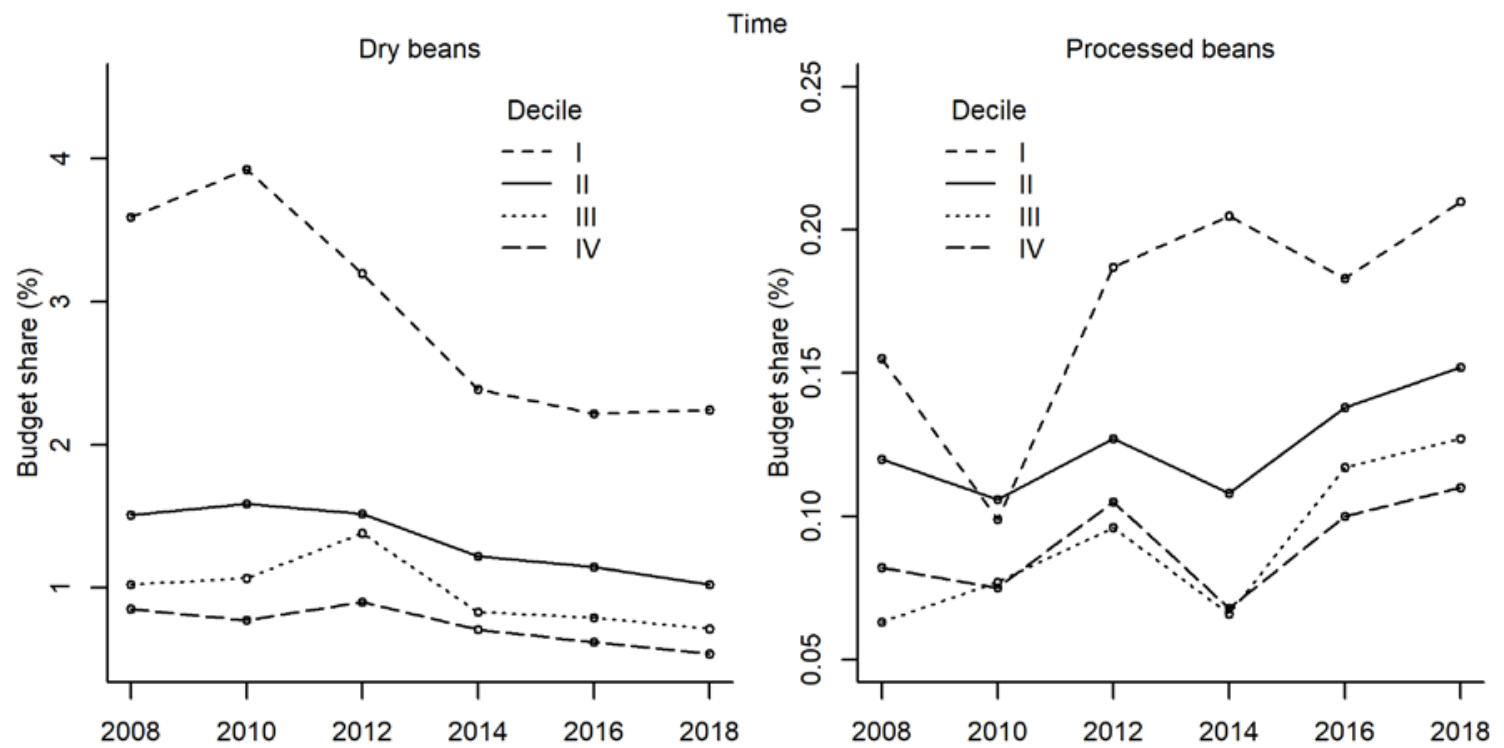

Figure 2: Average budget share for dry bean and processed bean (\%) for the lower income deciles (quarterly data), 2008-2018. Source: own elaboration with data from INEGI 2019a 
Table 2: Average budget share (\%) for animal-based foodstuffs and non-processed pulses by income decile (quarterly data), 2008-2018

\begin{tabular}{|c|c|c|c|c|c|c|c|c|c|c|c|}
\hline \multirow[b]{2}{*}{ ENIGH $^{1}$} & \multicolumn{10}{|c|}{ Income decile ${ }^{2}$} & \multirow[b]{2}{*}{ Code } \\
\hline & $\mathrm{I}^{3}$ & II & III & IV & $\mathrm{V}$ & VI & VII & VIII & IX & $\mathrm{X}$ & \\
\hline 2008 & 14.440 & 10.333 & 8.669 & 7.903 & 7.436 & 6.784 & 5.485 & 4.624 & 3.811 & 2.378 & Animal $^{4}$ \\
\hline 2010 & 16.202 & 10.856 & 9.683 & 8.284 & 7.525 & 6.931 & 6.037 & 5.131 & 4.173 & 2.575 & Protein \\
\hline 2012 & 15.994 & 10.556 & 10.084 & 8.324 & 8.137 & 7.020 & 6.597 & 5.265 & 4.314 & 2.700 & \\
\hline 2014 & 14.661 & 10.650 & 10.000 & 9.204 & 8.412 & 7.360 & 6.716 & 6.060 & 4.776 & 3.026 & \\
\hline 2016 & 13.797 & 10.155 & 8.960 & 8.269 & 7.450 & 6.444 & 6.140 & 5.154 & 4.229 & 2.754 & \\
\hline 2018 & 13.496 & 9.902 & 8.969 & 8.052 & 7.481 & 6.653 & 6.043 & 5.200 & 4.380 & 2.804 & \\
\hline 2008 & 0.188 & 0.108 & 0.100 & 0.065 & 0.072 & 0.053 & 0.040 & 0.031 & 0.017 & 0.012 & Pulses \\
\hline 2010 & 0.219 & 0.125 & 0.108 & 0.073 & 0.074 & 0.056 & 0.040 & 0.036 & 0.025 & 0.012 & Non-proc. \\
\hline 2012 & 0.160 & 0.113 & 0.106 & 0.078 & 0.048 & 0.075 & 0.040 & 0.034 & 0.020 & 0.012 & \\
\hline 2014 & 0.121 & 0.147 & 0.109 & 0.079 & 0.088 & 0.074 & 0.040 & 0.034 & 0.030 & 0.012 & \\
\hline 2016 & 0.198 & 0.120 & 0.102 & 0.081 & 0.061 & 0.055 & 0.041 & 0.031 & 0.022 & 0.012 & \\
\hline 2018 & 0.172 & 0.116 & 0.098 & 0.072 & 0.068 & 0.063 & 0.048 & 0.038 & 0.027 & 0.015 & \\
\hline
\end{tabular}

${ }^{1}$ Following the procedure whereby the expenditure on other foodstuffs reported in the 'concentrado' tables were obtained. ${ }^{2}$ The expansion factor was used when determining the income deciles. ${ }^{3}$ Budget share for households with no income was set to 0 for decile I. ${ }^{4}$ Animal protein $=$ carnes + huevo + pescado, from the 'concentrado' tables. Source: own elaboration with data from INEGI, 2019a.

this commodity (measured as the domestic production to apparent national consumption ratio) (Figure 1), since the increase in the domestic demand (driven by population growth) was met by increasing imports.

Among the factors that influence the spatial variation in the quantity and sources of protein consumed, income and cost stand out, as well as the effect of the environmental conditions on the selection of staple crops at the local level (Grigg, 1995). In the paper at hand, we set out to examine Engel's law (i.e. the principle stating that poorer households dedicate a higher share of their income to food than richer households), applied to both dry bean and processed bean. In economics, the so-called Engel curves relate expenditure on different commodities and income at the household level. The latest data available on household expenditure and income in Mexico, is provided by the 2018 national survey 'Encuesta Nacional de Ingresos y Gastos de los Hogares’ (ENIGH).
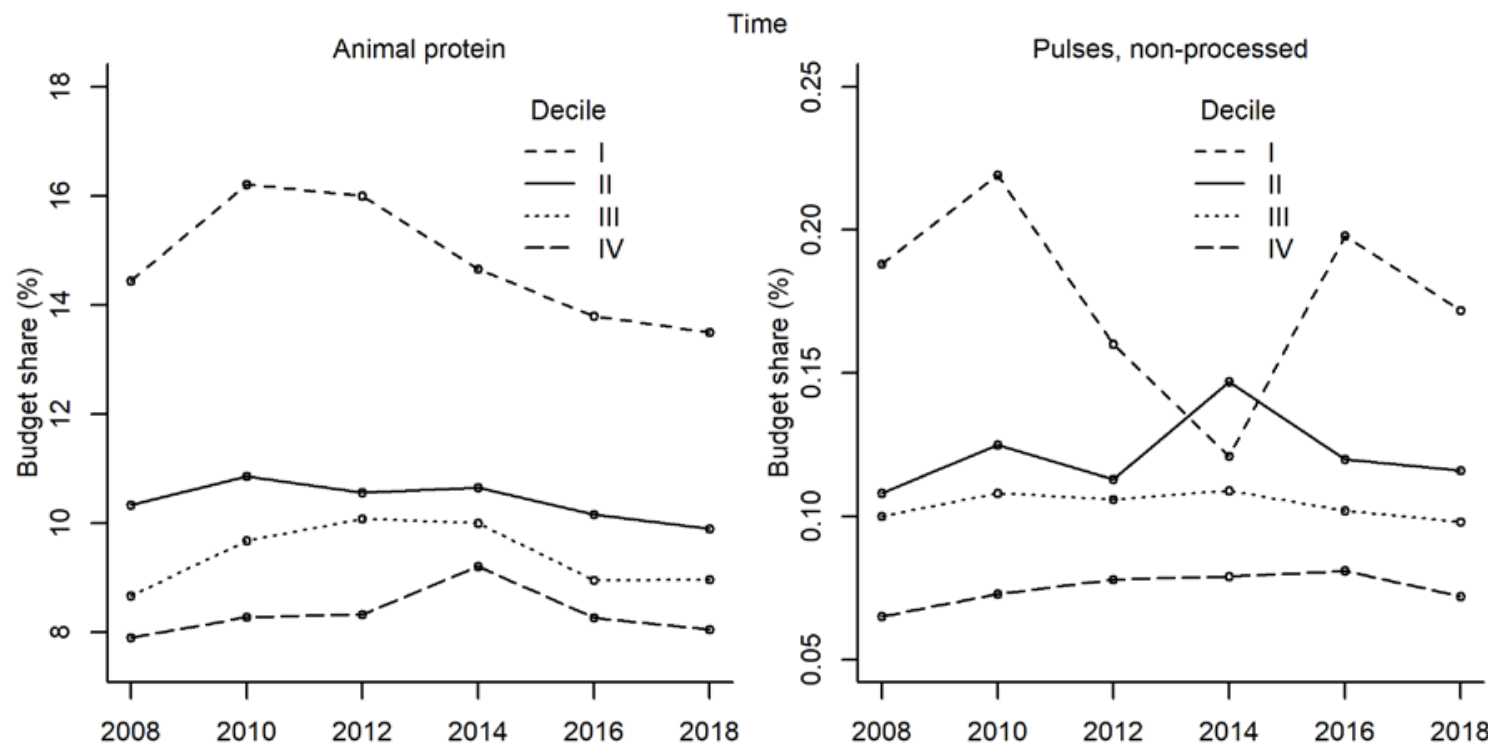

Figure 3: Average budget share for animal-based foodstuffs and non-processed pulses (\%) for the lower income deciles (quarterly data), 2008-2018. Source: own elaboration with data from INEGI 2019a 
Table 1 displays the budget share (i.e. the expenditure to income ratio) for both dry bean and industrialized bean across income deciles (quarterly current income). Engel's law seems to hold in the two cases. However, a closer look at the evolution of household expenditure reveals that households in the lower income deciles tend to spend far more on dry bean than on processed bean (Figure 2).

The analysis of household expenditure on dry bean is supplemented with an analysis of the expenditure on other sources of proteins. Table 2 displays the budget share for both animal-based sources of proteins (eggs, fish, and meat) and non-processed pulses (chickpeas, lentils, lima beans, and peas), during the period 2008-2018. Furthermore, the Figure 3 shows the average budget shares for animal-based foods and non-processed pulses for the lower four income deciles in the ten years' period.

\section{MATERIALS AND METHODS}

The 2018 ENIGH contains a set of zero-expenditure households for both dry bean and processed bean (Table 3). In single-equation representations of Engel curves, the Heckman (or Heckit) two-step procedure has been used to circumvent this censored-response problem (Saha et al., 1997).

The Heckman estimation method of Engel curves is based on the idea that censored data on household expenditure can be seen as a combination of a selection

Table 3: Descriptive statistics of the expenditure variables used in the analysis

\begin{tabular}{lllrlll}
\hline Code & Commodity & \% of non-zeros & Mean $^{1}$ & Std. Dev. & Min & Max \\
\hline A137 & Dry bean & 33.24 & 138.80 & 256.87 & 0.00 & $6,428.57$ \\
A142 & Processed bean & 11.81 & 37.28 & 129.47 & 0.00 & $4,049.96$ \\
\hline
\end{tabular}

${ }^{1}$ Mexican Pesos. Source: own elaboration with data from INEGI, 2019a.

mechanism for the decision to purchase and a model for the level of the expenditure, which applies only to the sample of households with actual expenditure.

The procedure starts off with the equation that determines the sample selection:

$z_{i}=\boldsymbol{w}_{i}^{\prime} \boldsymbol{\gamma}+u_{i}$

Where $z_{i}$ is an indicator variable equal to 1 if expenditure occurs in household $i$ and 0 otherwise, $\boldsymbol{w}_{i}$ is a vector of observed socio-demographic characteristics of the household that affect the purchase decision, and $\gamma$ is a vector of coefficients which is determined by the Maximum Likelihood (ML) estimation of a probit model where:
$\operatorname{Pr}\left[z_{i}=1 \mid \boldsymbol{w}_{i}\right]=\Phi\left(\boldsymbol{w}_{i}^{\prime} \boldsymbol{\gamma}\right)$

This step is applied on the full sample of households and its purpose is to provide with estimates of the bias correction term (also known as the inverse Mills ratio, or IMR) given by:

$\hat{\lambda}_{i}=\phi\left(\boldsymbol{w}_{i}^{\prime} \widehat{\gamma}\right) / \Phi\left(\boldsymbol{w}_{i}^{\prime} \widehat{\gamma}\right)$

Where $\Phi$ is the standard normal cumulative distribution function and $\phi$ is the standard normal probability density function.

In the second step, Ordinary Least Squares (OLS) are applied on the model that represents the Engel curve plus the estimated bias correction term in an equation like:

$y_{i}=\boldsymbol{x}_{i}^{\prime} \boldsymbol{\beta}+\theta \hat{\lambda}_{i}+\varepsilon_{i}$

Where $x_{i}$ represents a vector of socio-demographic features of the household that affect the level of expenditure on a given commodity. This step uses only the truncated sample where positive expenditure is observed, i.e. where $y_{i}>0$ or equivalently where $z_{i}=1$.

In the paper at hand, the equation of the selection mechanism is given by:

$z_{i}=\gamma_{1}+\gamma_{2} \ln ($ income $)+\sum_{k=3}^{k} \gamma_{k} w_{k}+u_{i}$

Some functional forms used to examine Engel's law include: double logarithmic, quadratic, semi-logarithmic and Working-Lesser. The latter approach relates budget share $y_{i}$ and the logarithm of income; it also allows a direct test of Engel's law (Holcomb et al., 1995). The Engel curve used in the second step of the Heckit follows the Working-Lesser form defined by:

$$
y_{i}=\beta_{1}+\beta_{2} \ln \left(\text { income }_{i}\right)+\sum_{k=3}^{k} \beta_{k} x_{k, i}+\theta \hat{\lambda}_{i}+\varepsilon_{i}
$$

This analysis is supplemented with a corrected estimate of the income elasticity of the budget share given by (at the mean of the data):

$e_{s}=1+\frac{1}{E\left(y_{i}\right)}\left[\hat{\beta}_{2}+\hat{\theta} E\left(\frac{\partial}{\partial w_{2}} \hat{\lambda}_{i}\right)\right]$

Where $w_{2}=\ln$ (income). Which is equivalent to (Saha et al., 1997):

$e_{s}=1+\frac{1}{E\left(y_{i}\right)}\left[\hat{\beta}_{2}-\hat{\theta} \hat{\gamma}_{2}\left\{E\left(\boldsymbol{w}_{i}^{\prime} \hat{\gamma}\right) E\left(\hat{\lambda}_{i}\right)+E\left(\hat{\lambda}_{i}\right)^{2}\right\}\right]$ 
The data used in this analysis is provided by Mexico's Instituto Nacional de Estadística y Geografía and are representative at the national level. The $2018 \mathrm{ENIGH}$ provides with a sample of 74,647 households in a table labeled as 'concentradohogar', with records on their expenditure on selected food groups, as well as their sociodemographic features, including size and income. In this analysis, the income variable corresponds to quarterly current income.

The expenditure on dry bean was obtained following the same procedure used to get the expenditures on the food groups recorded in the 'concentradohogar' table, i.e. as the summation of the quarterly expenditure (gasto trimestral) on the code A137 from the 'gastoshogar' table plus the summation of the quarterly expenditure on the same code from the 'gastospersona' table. For the expenditure on processed bean, we replicated the procedure using the code A142.

In order for the budget shares to be confined between zero and one, households that reported having either no-income or expenditure on dry bean greater than income were removed from the sample. This rendered a subset of 74,637 households.

The sociodemographic characteristics considered in this paper are: 1) income (IngCor); 2) size of locality (TamLoc); 3) region (Region); 4) household class (ClaseHog); 5) education of the head of the household (EducaJefe); 6) sex of the head of the household (SexoJefe); 7) age of the head of the household (EdadJefe); 8) number of grown-ups (Mayores); 9) size of the household (TotInteg); and 10) socio-economic strata (EstSocio). We added dummy variables to indicate expenditure on: 11) dry bean (A137_dum); 12) processed bean (A142_dum); 13) meat products (Carnes_dum); 14) eggs (Huevo_dum); and 15) fish (Pescado_dum). The levels for size of locality (number of inhabitants) are: 100,000 and more $=1$; $15,000-99,999=2 ; 2,500-14,999=3 ; 2,500$ and less $=4$. The region variable is a categorical one with the following levels: NW (Baja California, Baja California Sur, Chihuahua, Durango, Sinaloa, and Sonora); NE (Coahuila, Nuevo León, and Tamaulipas); W (Colima, Jalisco, Michoacán, and Nayarit); E (Hidalgo, Puebla, Tlaxcala, and Veracruz); CN (Aguascalientes, Guanajuato, Querétaro, San Luis Potosí, and Zacatecas); CS (Ciudad de México, Estado de México, and Morelos); SW (Chiapas, Guerrero, and Oaxaca); and SE (Campeche, Quintana Roo, Tabasco, and Yucatán). The education of the head of the household ranges from: Without instruction $=1$, to Graduate $=11$. The levels for sex of the head of the household are: Male $=1$; and Female $=2$. The levels for socioeconomic strata and household class are inherited from the ENIGH terminology. The socioeconomic strata are: Lower $=1$; Lower middle $=2$; Upper middle $=3$; and
Upper $=4$. Finally, the household classes are: One-person $=1$; Nuclear $=2$; Extended $=3$; Composite $=4$; and Coresident $=5$.

\section{RESULTS}

Table 4 shows the OLS Engel curve estimates for dry bean and processed bean for Mexico, using the 2018 data. It also shows the ML for the probit model used in the first stage of the Heckit procedure for dry bean. The results obtained show that the coefficient associated with the IMR is significant only for dry bean, which indicates that the correlation between the error term of the decision to purchase this commodity and the budget share of the same is different than zero.

The use of the Heckit procedure is appropriate in the case of dry bean; therefore, household expenditure on this commodity can be represented as a two-stage process. The variables included in the probit model were determined on the basis of the Akaike Information Criterion (AIC), by step-wise regression. Regarding the decision to purchase dry bean, the income variable is statistically significant. This result indicates that income affects negatively the probability of purchasing this commodity. The effect of household size is positive and statistically significant, which indicates that having a larger household increases the propensity to spend on dry bean.

In order to determine the final form of the WorkingLesser structure in the second step of the Heckit procedure, we tested for collinearity in a model with the same regressors used for the probit in the first stage, plus the IMR. Then, we removed the variable with the highest variance inflation factor (VIF) keeping the IMR, so that in the final model all VIF's fell below the cut-off value of 10 . Thus, the variables in the OLS model for dry bean are a subset of the variables included in the probit model.

Both OLS models from Table 4 exhibit heteroskedasticity. It has been pointed out that the standard errors and the heteroskedasticity-robust standard errors of the OLS estimates provided by the second stage of the Heckit models, are incorrect. Although formulas to overcome this problem are available, their implementation is not always easy; however, one alternative is to use bootstrapped standard errors (Cameron \& Trivedi, 2005, p. 550). We followed this approach for dry bean, whereas in the case of processed bean, we present heteroskedasticity-robust standard errors.

The Working-Lesser structure reported negative and statistically significant parameter estimates for the logarithm of current income for dry bean and processed bean.

The corrected conditional elasticity estimated at the mean of the data for dry bean is -0.1056 . Whereas, the 
Table 4: Heckit and OLS estimates of the Engel curve for dry bean and for processed bean

\begin{tabular}{|c|c|c|c|}
\hline \multirow[b]{3}{*}{ Regressor } & \multicolumn{3}{|l|}{ Dependent variable: } \\
\hline & $1^{\text {st }}$ step: $z_{i, A 137}$ & $2^{\text {nd }}$ step: $y_{i, A 137}$ & $y_{i, A 142}$ \\
\hline & Probit-ML & OLS & OLS \\
\hline Log(IngCor) & $-0.1847^{\star * \star}(0.0088)$ & $-0.0212^{* * *}(0.0005)$ & $-0.0135^{* * *}(0.0012)$ \\
\hline TamLoc $=2$ & $0.0912^{* * *}(0.0176)$ & $-0.0002(0.0003)$ & \\
\hline TamLoc $=3$ & $0.1401^{* * *}(0.0181)$ & $-0.0004(0.0003)$ & \\
\hline TamLoc $=4$ & $0.1322^{\star * \star}(0.0164)$ & $0.0013^{\star \star \star}(0.0003)$ & \\
\hline Region $=$ NW & $-0.0957^{* * *}(0.0169)$ & $0.00004(0.0004)$ & $0.0014^{* * *}(0.0004)$ \\
\hline Region $=$ SE & $0.1243^{* * *}(0.0199)$ & $-0.0034^{\star * \star}(0.0004)$ & $-0.0030^{* * *}(0.0004)$ \\
\hline Region $=$ SW & $-0.0152(0.0203)$ & $0.0022^{* * *}(0.0006)$ & $0.0002(0.0005)$ \\
\hline Region $=$ CS & $-0.0145(0.0207)$ & $-0.0004(0.0005)$ & $-0.0027^{* * *}(0.0005)$ \\
\hline Region $=\mathrm{NE}$ & $-0.1725^{\star * *}(0.0200)$ & $0.0010^{\star}(0.0006)$ & $0.0002(0.0007)$ \\
\hline Region $=\mathrm{W}$ & $0.0271(0.0199)$ & $-0.0006(0.0004)$ & $-0.0002(0.0005)$ \\
\hline Region = E & $0.0791^{* * *}(0.0196)$ & $-0.0013^{* * *}(0.0005)$ & $-0.0032^{* * *}(0.0005)$ \\
\hline ClaseHog $=2$ & $0.0973^{* * *}(0.0253)$ & $-0.0039^{* * *}(0.0009)$ & \\
\hline ClaseHog $=3$ & $0.0338(0.0306)$ & $-0.0040^{* * *}(0.0010)$ & \\
\hline ClaseHog $=4$ & $0.0240(0.0687)$ & $-0.0024(0.0016)$ & \\
\hline ClaseHog $=5$ & $-0.3212^{* * *}(0.1169)$ & $-0.0002(0.0023)$ & \\
\hline EducaJefe $=2$ & $-0.0630(0.1505)$ & $-0.0028(0.0032)$ & $-0.0006(0.0040)$ \\
\hline EducaJefe $=3$ & $-0.0249(0.0216)$ & $-0.0025^{* * *}(0.0007)$ & $-0.0027^{* *}(0.0012)$ \\
\hline EducaJefe $=4$ & $-0.0663^{* * *}(0.0223)$ & $-0.0034^{* * *}(0.0007)$ & $-0.0026^{* *}(0.0013)$ \\
\hline EducaJefe $=5$ & $-0.1081^{* * *}(0.0336)$ & $-0.0035^{* * *}(0.0009)$ & $-0.0028^{* *}(0.0014)$ \\
\hline EducaJefe $=6$ & $-0.1385^{* * *}(0.0226)$ & $-0.0040^{* * *}(0.0007)$ & $-0.0025^{* *}(0.0012)$ \\
\hline EducaJefe $=7$ & $-0.2427^{* * *}(0.0359)$ & $-0.0040^{\star * *}(0.0008)$ & $-0.0033^{* * *}(0.0012)$ \\
\hline EducaJefe $=8$ & $-0.2225^{\star * *}(0.0265)$ & $-0.0030^{* * *}(0.0007)$ & $-0.0012(0.0016)$ \\
\hline EducaJefe $=9$ & $-0.3497^{* * *}(0.0414)$ & $-0.0005(0.0009)$ & $-0.0017(0.0013)$ \\
\hline EducaJefe $=10$ & $-0.2934^{\star * *}(0.0296)$ & $0.0023^{* * *}(0.0008)$ & $-0.0004(0.0014)$ \\
\hline EducaJefe $=11$ & $-0.3185^{* * *}(0.0524)$ & $0.0073^{* * *}(0.0012)$ & $0.0038^{* *}(0.0018)$ \\
\hline SexoJefe $=2$ & & & $-0.0013^{* * *}(0.0004)$ \\
\hline Log(EdadJefe $)$ & $0.1132^{* * *}(0.0205)$ & $0.0028^{* * *}(0.0005)$ & $0.0021^{* * *}(0.0004)$ \\
\hline Log(Mayores) & $0.2122^{* * *}(0.0230)$ & $0.0033^{* * *}(0.0006)$ & \\
\hline $\log ($ TotInteg $)$ & $0.2248^{* * *}(0.0224)$ & $0.0041^{\star * \star}(0.0006)$ & $0.0031^{* * *}(0.0006)$ \\
\hline EstSocio $=2$ & $-0.2147^{* * *}(0.0147)$ & $-0.0044^{* * *}(0.0003)$ & $0.00002(0.0007)$ \\
\hline EstSocio $=3$ & $-0.3129^{\star * \star}(0.0230)$ & $-0.0028^{* * *}(0.0005)$ & $0.0002(0.0009)$ \\
\hline EstSocio $=4$ & $-0.3531^{\star * *}(0.0311)$ & $0.0007(0.0006)$ & $0.0022^{\star *}(0.0010)$ \\
\hline A142_dum $=1$ & $-0.5798^{\star * *}(0.0176)$ & $-0.0025^{\star * \star}(0.0005)$ & \\
\hline A137_dum = 1 & & & $-0.0030^{\star * *}(0.0003)$ \\
\hline Carnes_dum $=1$ & $0.4133^{\star * \star}(0.0143)$ & $-0.0037^{\star * *}(0.0006)$ & $-0.0019^{* * *}(0.0007)$ \\
\hline Huevo_dum = 1 & $0.4305^{\star * *}(0.0112)$ & & $0.0005(0.0005)$ \\
\hline Pescado_dum = 1 & $0.1379^{* * *}(0.0130)$ & $0.0011^{\star * *}(0.0003)$ & $0.0006(0.0005)$ \\
\hline A137_mr & & $0.0019^{* *}(0.0010)$ & \\
\hline Constant & $0.1617(0.1199)$ & $0.2270^{\star * *}(0.0047)$ & $0.1449^{* * *}(0.0115)$ \\
\hline Observations & 74,637 & 24,808 & 8,818 \\
\hline R2 & & 0.4041 & 0.2674 \\
\hline Log Likelihood & $-41,773.2200$ & & \\
\hline Akaike Inf. Crit. & $83,618.4300$ & & \\
\hline Residual Std. Error & & $0.0192(\mathrm{df}=24772)$ & $0.0148(\mathrm{df}=8789)$ \\
\hline F Statistic & & $479.9184^{\star * \star}(\mathrm{df}=35 ; 24772)$ & $114.5816^{\star * *}(\mathrm{df}=28 ; 8789)$ \\
\hline
\end{tabular}

Notes: Standard errors in parentheses; in the case of dry bean, bootstrapped estimates after 3,000 samples; in the case of processed bean, heteroskedasticity-robust. Significance levels: ${ }^{*} p<0.1 ;{ }^{* *} p<0.05 ;{ }^{* * *} p<0.01$. Own elaboration with data from INEGI, 2019a. 
elasticity for processed bean is -0.2286 . The negative sign indicates that both commodities are inferior goods.

\section{CONCLUSIONS}

The use of pulses for the attainment of policy objectives in several areas demands the reversing of the downward trend in consumption that these commodities have displayed worldwide. In the present paper, the strategic importance of dry bean for Mexico is pointed out; this pulse remains as the leading source of plant-based proteins among Mexicans, since it exceeds the expenditure that households make on other pulses. However, a closer look on household expenditure revealed that the abovementioned trend manifested itself across income deciles during the last decade.

To understand the last link of the marketing chain for dry bean in Mexico, we set out to analyze household expenditure on several protein sources, including both dry bean and processed bean. For this purpose, budget share Engel curves were estimated for the two commodities using the 2018 ENIGH sample of households. Our results are in alignment with the principle stated by Engel's law, and both dry bean and processed bean turned out to be inferior goods. Therefore, policy measures aimed at the attainment of environmental, nutritional, and health goals, based on the use of dry bean and other pulses, ought to set out to change the relationship between expenditure on this commodities and income, i.e. turn them into normal goods. One alternative is the advancement of processed versions of these commodities.

Other trends worth mentioning in Mexico' market for dry bean are: the slight erosion of a self-sufficiency index in the post-liberalization era of the economy, the decline in the per-capita consumption of this commodity, and the stagnation of the production level (notwithstanding the considerable year-over-year changes). Finally, some of the expected outcomes from policies aimed at furthering dry bean production are: 1) increases in the production levels as more productive land is allocated to this end, and a decline in prices due to higher productivity.

\section{REFERENCES}

Aiking, H. (2011). Future protein supply. Trends in Food Science \& Technology, 22(2-3), 112-120. https://doi.org/10.1016/j. tifs.2010.04.005

Bekkers, E., Brockmeier, M., Francois, J., \& Yang, F. (2017). Local Food Prices and International Price Transmission. World Development, 96, 216-230. https://doi.org/10.1016/j.worlddev.2017.03.008
Calles, T., del Castello, R., Baratelli, M., Xipsiti, M. \& Navarro, D. K. (2019). International Year of Pulses - Final report. Rome: FAO. https://doi.org/10.1007/s12665-019-8106-6

Cameron, A. C., \& Trivedi, P. K. (2005). Microeconometrics: Methods and Applications. Cambridge: Cambridge University Press. https://doi.org/10.1017/CBO9780511811241

De Boer, J., Schösler, H., \& Aiking, H. (2014). “Meatless days” or "less but better"? Exploring strategies to adapt Western meat consumption to health and sustainability challenges. Appetite, 76, 120-128. https://doi.org/10.1016/j.appet.2014.02.002

FAO. (2019). FAOSTAT. Retrieved May 24, 2019, from http:// www.fao.org/faostat/en/\#data

Gandhi, V. P., \& Zhou, Z. (2014). Food demand and the food security challenge with rapid economic growth in the emerging economies of India and China. Food Research International, 63, 108-124. https://doi.org/10.1016/j.foodres.2014.03.015

Grigg, D. (1995). The pattern of world protein consumption. Geoforum, 26(1), 1-17. https://doi.org/10.1016/00167185(94)00020-8

Holcomb, R. B., Park, J. L., \& Capps, O. (1995). Revisiting Engel's Law: Examining Expenditure Patterns for Food at Home and Away From Home. Journal of Food Distribution Research, 26, $1-8$.

INEGI. (2019a). Encuesta Nacional de Ingresos y Gastos de los Hogares. Retrieved from https://www.inegi.org.mx/programas/enigh/nc/2018/

INEGI. (2019b). Instituto Nacional de Estadística y Geografía. Retrieved from https://www.inegi.org.mx/datos/

Parry, M. L., Rosenzweig, C., Iglesias, A., Livermore, M., \& Fischer, G. (2004). Effects of climate change on global food production under SRES emissions and socio-economic scenarios. Global Environmental Change, 14(1), 53-67. https:// doi.org/10.1016/j.gloenvcha.2003.10.008

Saha, A., Capps, O., \& Byrne, P. J. (1997). Calculating marginal effects in models for zero expenditures in household budgets using a Heckman-type correction. Applied Economics, 29(10), 1311-1316. https://doi.org/10.1080/00036849700000021

Sathe, S. K. (2002). Dry Bean Protein Functionality. Critical Reviews in Biotechnology, 22(2), 175-223. https://doi. org/10.1080/07388550290789487

Stehfest, E., Bouwman, L., van Vuuren, D. P., den Elzen, M. G. J., Eickhout, B., \& Kabat, P. (2009). Climate benefits of changing diet. Climatic Change, 95(1-2), 83-102. https://doi. org/10.1007/s10584-008-9534-6

Valin, H., Sands, R. D., van der Mensbrugghe, D., Nelson, G. C., Ahammad, H., Blanc, E., ... Willenbockel, D. (2014). The future of food demand: understanding differences in global economic models. Agricultural Economics, 45(1), 51-67. https://doi.org/10.1111/agec.12089

Vranken, L., Avermaete, T., Petalios, D., \& Mathijs, E. (2014). Curbing global meat consumption: Emerging evidence of a second nutrition transition. Environmental Science and Policy, 39, 95-106. https://doi.org/10.1016/j.envsci.2014.02.009

Westhoek, H., Lesschen, J. P., Rood, T., Wagner, S., De Marco, A., Murphy-Bokern, D., ... Oenema, O. (2014). Food choices, health and environment: Effects of cutting Europe's meat and dairy intake. Global Environmental Change, 26(1), 196-205. https://doi.org/10.1016/j.gloenvcha.2014.02.004 